\title{
Pancreatic Dysfunction Associated With Severe Acute Anticholinesterase Insecticide Poisoning In Adults
}

\author{
Mohamed AM Khalaf, Mohamed F. Abbas ${ }^{1}$ and Samira M. Saleh ${ }^{2}$ \\ 1 Department of Forensic Medicine and Clinical Toxicology Faculty of Medicine, University of Minia, Minia, Egypt. \\ 2 Department of Forensic Medicine and Clinical Toxicology , Faculty of Medicine, University of South Valley, Qena, Egypt.
}

\begin{abstract}
Background: The current study was carried out to study the effect of severe acute organophosphate compounds (OP) toxicity on the pancreatic profile in adults. Subjects and Methods: Six ml of venous blood were drawn from 260 patients (18-52 years) with severe acute OP toxicity who were admitted to the intensive care unit of Minia Poisoning Control Centre (PCC) during the period from May the $1^{\text {st }}, 2012$ to April, the $30^{\text {th }}$, 2014, and also from 20 healthy adults of the same age group acting as control. Blood samples were analyzed for: Pseudocholinestrase (PChE), serum insulin, serum $\alpha$-amylase and serum lipase. Results: PChE level in intoxicated patients on the day of admission was highly significant decreased when compared with control. There was highly significant increase in the serum levels of amylase and lipase in intoxicated patients as compared to normal control group. In addition, there was highly significant increase in blood glucose level in intoxicated patients as compared with control group while there was no significant effect on the serum insulin level. A significant correlation was found between the degree of PChE inhibition and the elevation of serum amylase, lipase and serum glucose level. Conclusion: acute pancreatitis was evident in severe cases of OP intoxication on the day of admission, also OP -induced hyperglycemia is evident and most probably due to other cause rather than hypoinsulinemia.
\end{abstract}

Keywords Anticholinesterase, Insecticide ,Pancreatic dysfunction, Amylase, Lipase, Insulin, Hyperglycemia.

\section{Introduction}

$\mathrm{O}$ rganophosphate compounds (OP) are the most common chemical agents that cause pesticide poisoning. They affect all the organ systems in different ways. Some of the complications of OP poisoning are failure of respiration, myocardial infarction, risk of kidney cancer in children, delayed neuropathies and encephalopathy, fetal death, intrauterine growth retardation and congenital malformations (Kumar et al., 2010).

Currently more than 100 different OP compounds are used worldwide as insecticides. Because of widespread use and easy accessibility, these compounds result in a huge number of intoxications. Between 750000 and 3000000 human intoxications are estimated worldwide per year, resulting in several hundred thousands of fatalities annually. Accidental exposure is the main cause for mild poisonings and severe cases are mostly due to suicidal use (Yurumez et al., 2007). Weizman \& Sofer, (1992) and Sahin et al. (2002) reported that acute pancreatitis as a complication of OP intoxication is not an uncommon condition in adults and children. Pancreatic injury may be painless and diagnosed by hyperamylasemia, elevated serum lipase and hyperglycemia (Singh et al., 2007).

The current study was carried out to study the effect of severe acute OP toxicity on the pancreatic profile in adults.

\section{Subjects and methods}

The current study was conducted on 260 patients (18-52 years) with severe acute OP toxicity who were admitted to the intensive care unit of Minia Poisoning Control Centre (PCC) during the period from May the $1^{\text {st }}, 2012$ to April, the $30^{\text {th }}, 2014$. Also from 20 healthy volunteers of the same age were taken as control group.

Inclusion criteria: Patient having history of organophosphorus poisoning within 24 hours with muscarinic, nicotinic and central effects of acute of OP poisoning. The severity of OP poisoning was assessed by peradeniya OP poisoning scale where all the patients have overall score of 8 to 11 and diagnosed as severe poisoning (Senanayake et al., 1993).

Exclusion criteria: Patients with concomitant illness (diabetic, hepatic, cardiac, renal, lung or pancreatic 
disease), patients who consumed other poisons or drugs along with op compound and pregnant females or those taking oral contraceptive pills.

\section{Ethical consideration}

Participation in the study was voluntary, and all selected patients provided informed consent. The study was approved by the ethical committee of our institute

\section{Biochemical analyses}

Venous blood samples $(6 \mathrm{ml})$ were drawn from the patients and control group, kept into clean dry centrifuge tubes and left to stand for a few hours before centrifugation to avoid hemolysis. The serum was separated and then used for carrying out the following tests

Pseudochlinesterase (PChE) Level: It was determined by the enzymatic colorimetric method of Waber, (1966).

\section{Pancreatic functions tests:}

Serum $\alpha$-Amylase was determined by the enzymatic colorimetric method according to Junge, (1989).

Serum Lipase was determined by the turbidimetric method according to Ziegenhorn, (1979).

Insulin: Serum insulin level was measured with the immunoradiometric (IRMA) kit provided by Pasteur Diagnostics (Marnes La Coquette)

Blood glucose level: was measured by colorimetric method of Trinder, (1969).

\section{Statistical analysis}

The collected data was organized, tabulated and statistically analyzed using SPSS software statistical computer package version 16. Data were expressed as mean \pm standard deviation (SD). Student- $t$ test was used to differentiate between two means where probability (P); $\mathrm{P}<0.05$ : was considered significant. Correlations were estimated using Pearson's test where probability (P): $\mathrm{P}<0.05$ was considered significant.

\section{Results}

During period of study 260 patients with severe OP intoxication were admitted to the intensive care unit of Minia Poisoning Control Centre, most cases gave history of exposure to malathion, the most common clinical presentations were excessive salivation, vomiting, abdominal pain, fasciculations, convulsions, pin point pupil and respiratory depression.

The treatment goals include support of vital signs, prevention of further poisons absorption by decontamination, that is, removing all clothes and washing the skin and hair, gastric lavage, enhancement of poison elimination, administration of atropine $5 \mathrm{mg}$ i.v. followed by $2 \mathrm{mg}$ every $5 \mathrm{~min}$ till reach full atropinization guided by pupil size and heart rate. Specific antidote (toxogonin) was given till recovery occur. Regarding the outcome, 39 patients (15\%) died during the study mainly due to respiratory failure.

The results of the current study revealed that there was a highly significant decrease in Pseudocholinesterase level in intoxicated patients when compared to control group (Table 1-2 \& Fig. 1).

Regarding the pancreatic profile tests, there was a highly significant increase in the serum levels of amylase and lipase in intoxicated patients as compared to normal (Table 1-2 \& Fig. 2). According to the previous findings, acute pancreatitis was evident in the cases in this study on the day of admission.

In addition, there was a highly significant increase in blood glucose level as compared with control group (Table 1 \& Fig. 2). Moreover, there was no significant effect of acute OP intoxication on the serum insulin level in intoxicated patients as compared to normal (Table 1 \& Fig. 2).

A significant negative correlation was reported between the degree of PChE inhibition and the serum elevation of amylase, lipase and serum glucose level, but not with the insulin serum level (Table 3).

Table (1): Student -t test values of the pseudocholinesterase level (PChE) and the pancreatic profile tests in intoxicated patients and control group on the day of admission.

\begin{tabular}{|l|l|l|l|l|}
\hline \multicolumn{1}{|c|}{ Group } & $\begin{array}{l}\text { Control (n=20) } \\
\text { Mean + S.D }\end{array}$ & $\begin{array}{l}\text { Patients (n=260) } \\
\text { Mean + S.D }\end{array}$ & t-value & P-value \\
\hline PChE (U/L) & $2236.3 \pm 464.81$ & $152.23 \pm 26.37$ & 22.12 & $0.0001^{* *}$ \\
\hline Serum Amylase (U/L) & $53.74 \pm 18.52$ & $271.45 \pm 67.82$ & 0.914 & $0.0001^{* *}$ \\
\hline Serum Lipase (U/L) & $121.22 \pm 17.73$ & $312.41 \pm 56.47$ & 0.743 & $0.0001^{* *}$ \\
\hline Serum insulin (pmol/L) & 87.93 & 84.76 & 1.452 & 0.063 \\
\hline Glucose (mg/dL) & $99.45 \pm 8.94$ & $183.74 \pm 23.88$ & 0.856 & $0.0001^{* *}$ \\
\hline
\end{tabular}

PChE: pseudocholinesterase, $P^{* *}:<0.001$ Highly significant.

Table (2): Pearson's Correlation between the level of PChE and amylase, lipase, insulin and glucose levels.

\begin{tabular}{|l|l|l|}
\hline \multicolumn{1}{|c|}{ Statistical analysis } & r-value & P-value \\
\hline Parameter & & \\
\hline Lipase (U/L) & 0.851 & $0.001^{* *}$ \\
\hline Serum insulin (pmol/L) & 0.914 & $0.001^{* *}$ \\
\hline Glucose $(\mathrm{mg} / \mathrm{dL})$ & 1.237 & 0.078 \\
\hline
\end{tabular}

r: Pearson correlation, $P^{* *}:<0.001$ Highly significant. 


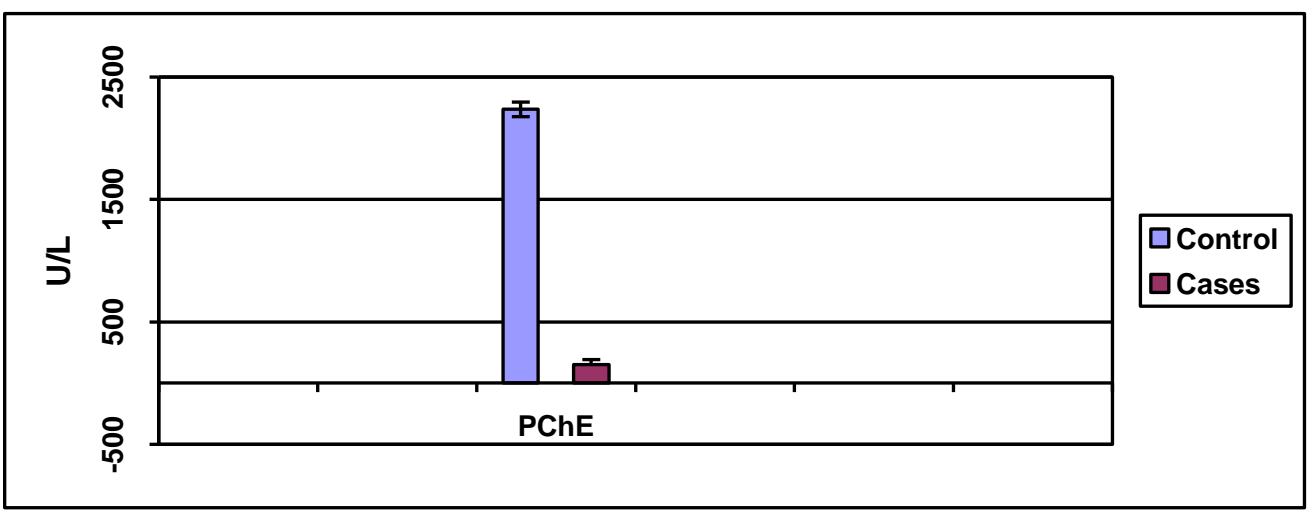

Fig. (1): Values of the pseudocholinesterase level (PChE) in intoxicated patients and control group on the day of admission.

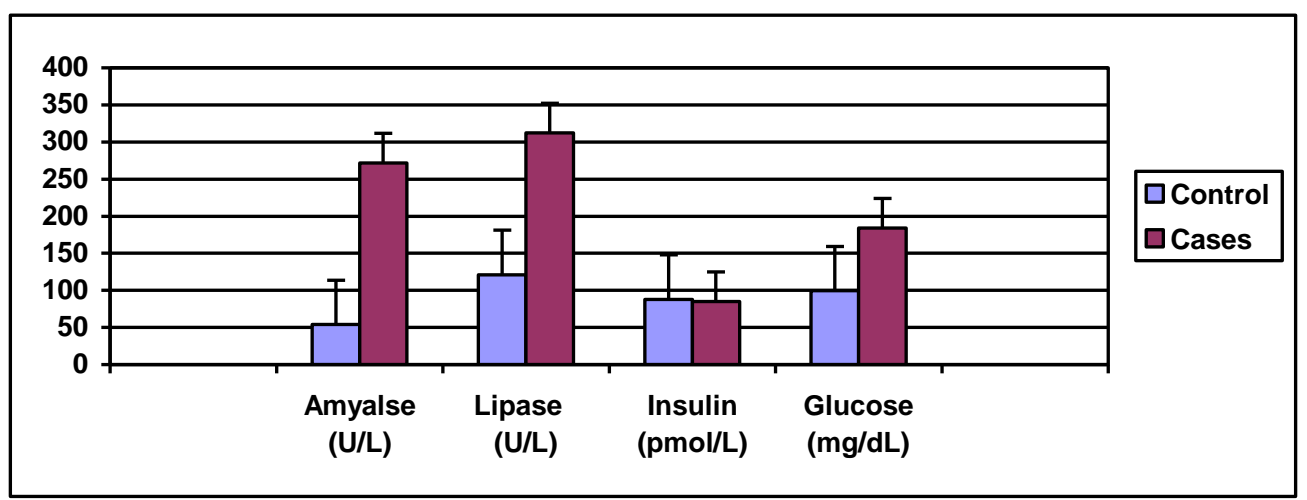

Fig. (2): Values of the pancreatic profile tests in intoxicated patients and control group on the day of admission.

\section{Discussion}

The results of the current study revealed that there was a highly significant increase in the serum levels of amylase, lipase and glucose in OP intoxicated patients when compared to control and significant negative correlation was reported between the degree of PChE inhibition and the serum elevation of amylase, lipase and serum glucose levels. These finding are in line with a study that has been conducted by Sumathi et al., (2014) in 53 patients intoxicated by OP and divided into three groups, where Group 3patients have increased amylase level and have shown significant negative correlation with serum cholinesterase levels

According to the previous findings, acute pancreatitis was evident in the cases under study on the day of admission. These findings are in agreement with Gokalp et al., (2005) and Ahmed Arshia et al., (2009), the later conducted a descriptive study Among 90 patients admitted with a positive history of organophosphate poisoning, hyperamylasemia was found in (31\%) of patients. Hyperlipasemia was seen in $(10 \%)$ of patients and pancreatitis was seen in $(2.2 \%)$ of patients.

In previous study, Sahin, et al., (2002) reported that acute pancreatitis with obvious hyperamylasemia occur in $12.76 \%$ of OP intoxication. Moreover, Singh et al., (2007) found that hyperamylasemia and acute pancreatitis occur in $46.95 \%$ of patients with OP poisoning. .
Also, Singh et al., (2003) and Rizos et al., (2004) reported that a serious adverse effect of carbamate intoxication is the development of acute pancreatitis which, depending on the severity of the inflammation, can lead to the development of complications such as ascites, intrapancreatic fluid and pancreatic pseudocyst formation

The exact mechanisms underlying OP-induced pancreatitis are still undefined, although it is believed to involve obstruction of pancreatic ducts and stimulation of exocrine pancreatic secretion due to cholinergic stimulation with subsequent Pancreatic ductal hypertension, in addition to that the enhanced reactive oxygen species may contribute (Kandalaft et al., 1991, Goodale et al., 1993 and Sevillano et al., 2003).

One of the serious findings of this study is the reported highly significant increase in blood glucose level. This is in accordance to Osmundson, (2002), who reported that a variety of biochemical abnormalities can occur with OP poisonings, most commonly described are hyperglycemia, hypokalemia, and hyponatremia. He stated that hyperglycemia is a well documented finding in anticholinesterase intoxication. Furthermore, significant hyperglycemia due to OP poisoning was reported by Seifert (2001), Sungur \& Guven, (2001), Rahimi \& Abdollahi (2007) and Lasram et al., (2008). 
A prominant finding of this study was that there was no significant effect of acute OP intoxication on the serum insulin level in intoxicated patients as compared to the control group. Moreover, a significant correlation was reported between the degree of PChE inhibition and the serum elevation of serum glucose level, but not with the insulin serum level. Rahimi \& Abdollahi (2007) ), stated that the rise in serum glucose level may be due to several mechanisms including physiological stress, oxidative stress, nitrosative stress, pancreatitis, inhibition of cholinesterase enzyme and disturbance in liver tryptophan metabolism. Furthermore, some authors explained the hyperglycemia in OP poisoning by marked catecholamine excess secretion which occur following continuous cholinergic stimulation induced by the poisoning, some experimental studies also suggest that persistent cholinergic over activity could also stimulate ACTH release from the anterior pituitary (Sudir et al., 2013).

\section{Conclusion}

acute pancreatitis and hyperglycemia are serious and evident complications in cases of severe acute OP poisoning on the first day of admission and that OPinduced hyperglycemia is most probably due to other cause rather than hypoinsulinemia.

\section{Recommendations}

serum glucose should be measured in every case of acute OP poisoning, attention of the physicians should be directed to the clinical manifestations of pancreatitis in those patients, serum amylase and lipase should be done to confirm or exclude the diagnosis. It is advised to conduct more studies to investigate the possible mechanisms of these reported changes, and so its avoidance or management.

\section{References}

Ahmed Arshia, Begum I, Aquil N, et al., (2009). Hyperamylasemia and acute pancreatitis following organophosphate poisoning. Pak J Med Sci; 25 (6):957-961.

Gokalp, O, Buyukvanh, B, Cicek E, et al. (2005). The effects of diazinon on pancreatic damage and ameliorating role of vitamin $\mathrm{E}$ and vitamin $\mathrm{C}$. Pesticide Biochemistry \& Physiology, 81, 123-128.

Goodale RL, Manivel JC, Borner JW, et al., (1993): Organophosphate sensitizes the human pancreas to acinar cell injury: an ultrastructural study. Pancreas; 8:171-175.

Junge W, (1989): Alpha amylase. Colorimetric test. Clin. Biochem; 22:109.

Kandalaft K, Liu S, Manivel C, et al., (1991): Organophosphate increases the sensitivity of human exocrine pancreas to acetylcholine. Pancreas; 6:398-403.

Kumar SV, Fareedullah M, Sudhakar Y, et al., 2010:Current review on organophosphorus poisoning. Scholar Research Library, 2 (4), , 199-215

Lasram, MM, Annabi, AB, Rezg R, et al. (2008). Effect of short-time Malathion administration on glucose homeostasis in Wistar rat.
Pesticide Biochemistry \& Physiology, 92, 114-119.

Osmundson M, (2002): Insecticides and pesticides. In: Emergency toxicology, $3^{\text {rd }}$ edition, Vaccellio P (editor), Lippincott Raven, Philadelphia, pp. 401-409.

Rahimi, R, \& Abdollahi, M. (2007). A review on the mechanisms involved in hyperglycemia induced by organophosphorus pesticides. Pesticide Biochemistry \& Physiology, 115121.

Rizos E, Liberopoulos E, Kosta P, et al., (2004): Carbofuran-Induced Acute Pancreatitis. JOP. J Pancreas (Online); 5:44-7.

Sahin I, Onbasi K, Sahin H, et al., (2002): The prevalence of pancreatitis in organophosphate poisonings. Hum Exp Toxicol; 21:175-7.

Seifert, J. (2001). Toxicological significance of the hyperglycemia caused by organophosphorous insecticides. Bulletin of Environmental Contamination \& Toxicology, 67, 463-469.

Senanayake N, de Silva HJ, Karalliedde LA, (1993) scale to assess severity in organophosphorus intoxication: POP scale. Hum Exp Toxicol. ;12:297-9.

Sevillano S, de la Mano, AM, Manso MA, et al., (2003). N-acetylcysteine prevents intraacinar oxygen free radical production in pancreatic duct obstruction-induced acute pancreatitis. Biochimica et Biophysica Acta, 20, 177-184.

Singh S, Bhardwaj U, Verma S, et al., (2007) Hyperamylasemia and acute pancreatitis following anticholinesterase poisoning. Hum Exp Toxicol. 26 (6): 467-71.

Singh S, Parthasarathy S, Sud A, et al., (2003): Acute pancreatitis following propoxyfur (Baygon) ingestion. J Assoc Physicians India; 51:78-9.

Sudir U, Chandrashekar, Pai R, et al. (2013): Glycemic changes in acute anticholinesterase insecticide poisoning. W Lond Med J 5: 27-33

Sumathi ME, Kumar SH, Shashidhar KN, et al., (2014): Prognostic significance of various biochemical parameters in acute organophosphorus poisoning. Toxicol Inter; 21(2): 167-71.

Sungur M and Guven M, (2001): Intensive care management of organophosphate insecticide poisoning. Crit Care, Mar, 7(6): 311:5.

Trinder P, (1969): Glucose GOD-PAP method (Enzymatic colorimetric methods). Ann. Clin. Biochem; 6:24.

Waber H, (1966): Kinetic colorimetric method for detection of cholinesterase. Dtsch. Med. Wschr; 91: 1927.

Weizman Z, Sofer S., (1992): Acute pancreatitis in children with anticholinesterase insecticide intoxication. Pediatrics; 90:204.

Yurumez ZY, Cemek M, Yavuz ZY, et al., (2007): Beneficial Effect of N-Acetyl-cysteine against Organophosphate Toxicity in Mice. Biol. Pharm. Bull. 30(3): 490-494. 
Ziegenhorn J, (1979): Methods of determination of lipase. Clin. Chem; 25:1067.

\section{الملخص العربيى}

اختلال وظائف البنكرياس المرتبط بالتسمم الحاد بالمبيدات الحشرية المضادة لانزيم الكولينستريز في البالغين

\section{وسميرة محمد صالحّ محمد عبد العظيم محمد خلف ومحمد فتحى عباس'}

أجريت الدراسة الحالية لاختبار مدى تاثير التسمم الحاد الشديد بالمركبات الفوسفاتية العضوية على مؤشرات وظائف البنكرياس فن الاشخاص

الطريقة: تم سحب ستة مل من الدم الوريدي من · بـ من المرضى الذين نقلوا الى وحدة العناية المركزة الملحقة بمركز علاج السموم بمحافظة المنيا و المصابين بالتسمم الحاد بالمركبات

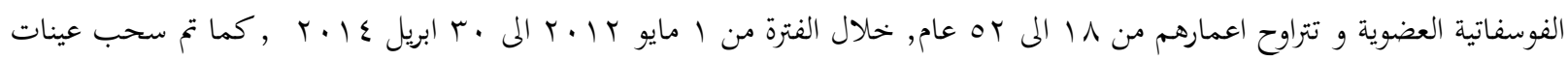
دم مماثلة من · ب من البالغين الأصحاء من نفس الفئة العمرية و اعتبارها بحموعة ضابطة. و بفحص عينات الدم وجدنا انه هناك الخفاض ملحوظ في مستوى انزيم Pseudocholinestrase في المرضى فن اليوم الاول من تعرضهم للاصابة بالتسمم الحاد بالمركبات الفوسفاتية العضوية بالمقارنة بالمحموعة الضابطة , كما انه هناك زيادة كبيرة في مستويات انزيم الأميليز والليبيز في الدم عند المرضى مقارنة بالمحموعة ضابطة.

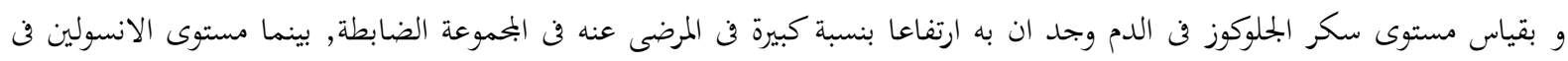
الدم لم يطرأ عليه اي تغير ذو أهمية.

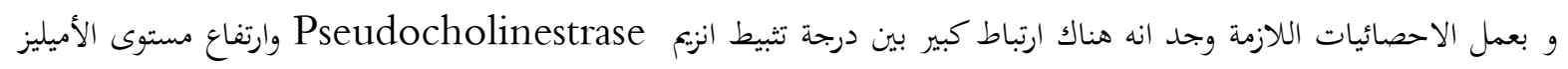
والليببز و الجلوكوز فن الدم. الخحلاصة: وفقا للنتائج السابقة تبين بوضوح حدوث التهاب حاد في البنكرياس في الاشخاص الذين تعرضوا للتسمم بالمركبات الفوسفاتية العضوية فن اليوم الاول من دخولمم مركز السموم , و ان ارتفاع مستوى سكر الجلوكوز في الدم في هذه الحالات نتج عن سبب اخر غير نقص لنص

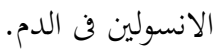
r قسم الطب الشرعى و السموم الاكلينكيةـ كلية الطب جامعة جنوب الو ادى 